\title{
Georg Wilhelm Friedrich Hegel
}

Differensen mellem det Fictheske og det Schellingske filosofiske system i forbindelse med Reinhold's "Bidrag til lettere oversigt over filosofiens tilstand i begyndelsen af det nittende århundrede, første hæefte". Jena, 1801.

\section{Indhold:}

Forerindring

Mange slags former, som forekommer ved den nuværende filosoféren

- Historisk anskuelse af filosofiske systemer

- Behov for filosofi

- Refleksion som instrument for filosoféren

- Spekulationens forhold til den sunde menneskeforstand

- Princippet for en filosofi i form af en absolut grundsætning

- Transcendental anskuelse

- Fornuftens postulater

- Filosoférens forhold til et filosofisk system

Fremstilling af det Fichteske system (ikke oversat)

Sammenligning af det Schellingske filosofiprincip med det Fichteske (ikke oversat)

Tillæg: Om Reinholds synspunkt og filosofi (ikke oversat)

\section{Forerindring}

Af de få offentlige ytringer, hvori man erkender en følelse af en forskel mellem det Fichteske og det Schellingske filosofiske system, lyser snarere bestræbelsen på at omgå forskellen eller på at skjule den for sig selv, end en tydelig 
bevidsthed om den. Hverken det umiddelbare blik på begge systemer som de foreligger for publikum, eller, blandt andre, Schellings svar på Eschenmayers idealistiske indvendinger mod naturfilosofien, har bragt denne forskellighed til udtryk. Tværtimod har f.eks. Reinhold haft så ringe anelse om denne forskel, at den først én gang etablerede antagelse om fuld identitet mellem begge systemer, også på dette punkt har forrykket hans synspunkt på Schellings system. Denne Reinholdske forvirring (mere end den truede - el. snarere bebudet som allerede skete - revolution af filosofien gennem dens tilbageføring til logikken) er anledning til følgende afhandling.

Den Kantske filosofi trængte til at få sin ånd adskildt fra bogstaven og til at få fremhævet det rent spekulative princip i forhold til det øvrige, som hørte til den ræsonnerende refleksion eller som kunne bruges af den. I princippet for deduktionen af kategorierne er denne filosofi ægte idealisme, og det er dette princip, som Fichte har fremhævet i ren og streng form og kaldt den Kantske filosofis ånd. At tingene i sig selv (igennem hvilke der ikke objektivt er udtrykt noget andet end modsætningens tomme form) atter sættes som hypostaseret og som absolut objektivitet, ligesom dogmatikernes ting, - at kategorierne dels selv bliver gjort til intelligensens hvilende, døde vifter, dels til det højeste princip gennem hvilket det udtryk, hvori det absolutte selv bliver udtalt, som f.eks. Spinozas substans, bliver tilintetgjort og hvor følgelig den negative ræsonneren atter, som før, kunne sætte sig i stedet for filosoféren, nu med mere prætention under navnet kritisk filosofi - denne omstændighed ligger højest i formen af den Kantske deduktion af kategorierne, ikke i dens princip eller ånd. Og hvis vi ikke fra Kant havde andre stykker af hans filosofi end dette, ville hin forvandling næsten have været ubegribelig. I hin deduktion af forstandsformerne udtales spekulationens princip, identiteten af subjekt og objekt, på det bestemteste. Denne teori om forstanden bliver båret til dåb af fornuften.

Når Kant derimod nu gør selve denne identitet, som fornuft, til genstand for filosofisk refleksion, forsvinder identiteten ved sig selv. Når forstanden var blevet behandlet med fornuft, bliver fornuften derimod behandlet med forstand. Her bliver det tydeligt, på hvilket underordnet trin identiteten mellem subjekt og objekt var blevet opfattet. Identiteten mellem subjekt og objekt indskrænker sig til tolv eller snarere kun til ni rene tankevirksomheder, for modalitet giver ingen egentlig objektiv bestemmelse. ${ }^{2}$ I den er der væsentligt ikke-identitet af subjekt og objekt. Uden for den objektive bestemmelse gennem kategorierne bliver der et uhyre empirisk rige af sansning og iagttagelse, en absolut aposterioritet, for hvilken der ikke er påvist nogen anden aprioritet end blot en subjektiv maksime fra den reflekterende dømmekraft. Det betyder, at ikke-identiteten blev ophævet til absolut grundsætning. Det 
kunne heller ikke være anderledes, efter at identiteten er trukket ud af ideen, af fornuftproduktet, dvs. at det fornuftige er blevet fjernet og er blevet sat som absolut modsætning til væren, - efter at fornuften var blevet fremstillet som den må blive tænkt af den endelige tænkning, dvs. af forstanden, nemlig som praktisk evne, ikke som absolut identitet, men som i uendelig modsætning, som den rene forstandsenheds evne. Herigennem opstår det kontrasterende resultat, at der for forstanden ikke er nogen forhåndenværende absolutte objektive bestemmelser, men at der derimod er det for fornuften.

Den rene tænkning af sig selv, identiteten af subjektet og af objektet i form af Jeg $=$ Jeg, er princippet i det Fichteske system. Og når man udelukkende holder sig til dette princip, som man i den Kantske filosofi holder sig til det transcendentale princip, som ligger til grund for deduktionen af kategorierne, så har man det dristigt udtalte, ægte princip for spekulationen. Men i samme øjeblik som spekulationen træder ud af det begreb, som den opstiller af sig selv, og former sig til system, så forlader den sig selv og sit princip, og kommer ikke tilbage i det samme igen. Den overgiver fornuften til forstanden og går over i bevidsthedens kæde af endeligheder, hvor ud fra den ikke igen rekonstruerer sig til identitet og til sand uendelighed. Princippet selv, den transcendentale anskuelse, får hermed den skæve stilling som noget modsat overfor den mangfoldighed, der er deduceret ud af det.

Absolutheden af systemet viser sig kun i form af dens fremtoning som den opfattes af den filosofiske refleksion, og denne bestemthed, som den får gennem refleksionen, altså endeligheden og modsatheden, bliver ikke fjernet. Princippet, subjekt-objektet, viser sig som et subjektivt subjekt-objekt. Det derfra deducerede får herigennem form af den rene bevidstheds, Jeg'ets = Jeg'ets betingelse, og den rene bevidsthed selv får form af betinget gennem en objektiv uendelighed, tids-progressionen in infinitum, i hvilken den transcendentale anskuelse fortaber sig og hvor Jeg'et ikke konstituerer sig til absolut selvanskuelse, hvor altså Jeg = Jeg forvandler sig til princippet: Jeg skal være lig Jeg. Det, som er sat i absolut modsætning, altså den til forstand ned-potenserede fornuft, bliver dermed princippet for de skikkelser, som det absolutte må give sig, og for deres videnskaber.

Disse to sider af det Fichteske system - den ene, ifølge hvilket det har opstillet begrebet om fornuft og om spekulation rent, dvs. gør filosofi mulig, den anden, ifølge hvilken det har sat fornuft og ren bevidsthed som ét og ophævede den fornuft til princip, som var opfattet i en endelig skikkelse - at adskille disse to sider skal kunne vise sig som selve sagens indre nødvendighed. Den ydre foranledning giver tidsbehovet og først og fremmest det $i$ dette tidsbehov svømmende Reinholds bidrag til oversigt over filosofiens tilstand i begyndelsen af det nye århundrede, i hvilken såvel den side, ud fra 
hvilken det Fichteske system er ægte spekulation og altså filosofi, er blevet overset, såvel som fra Schellings systems side, ud fra hvilken dette adskiller sig fra det Fichteske og modstiller det subjektive subjektobjekt det objektive subjektobjekt i naturfilosofien, og fremstiller begge som forenede i noget højere, end subjektet er.

Hvad tidens krav angår, så har den Fichteske filosofi vakt så meget opmærksomhed og epoke, at endog de, der erklærer sig som modstandere af den og som bestræber sig på at bringe egne spekulative systemer på banen, blot falder plumret og urent ind under den Fichteske filosofis princip uden af kunne afværge det. Den næstkommende fremtoning der præsenterer sig ved et epokegørende system, er misforståelserne og den kejtede opførsel hos dets modstandere. Når man kan sige om et system at det har gjort lykke, så har et alment behov i filosofien, der ikke i sig selv kunne bringe filosofi til verden for så ville det have befriet sig selv ved at skabe et system - vendt sig til det med instinktagtig tilbøjelighed. Og illusionen om den passive optagelse stammer fra, at der i det indre findes det, som systemet udtrykker, og som enhver fra nu af gør gældende i sin videnskabelige sfære eller livssfære. I denne betydning kan man ikke om det Fichteske system sige, at det har gjort lykke. Hvor meget dette end er tidsalderens ufilosofiske tendenser til besvær, så meget mere skal man tage i betragtning, at jo mere forstanden og nytten kan skaffe sig vægt og kan gøre sig begrænsede mål gældende, jo stærkere er den bedre ånds higen, specielt $\mathrm{i}$ den ubekymrede, endnu ungdommelige verden. Når fænomener som Taler over religionen ${ }^{3}$ ikke umiddelbart angår det spekulative behov, så tyder det og dets optagelse, men i højere grad den værdighed, som, med dunklere el. mere bevidst følelse, poesi og kunst overhovedet i deres sande omfang begynder at få, på en higen efter en filosofi, som har forsonet sig med den mishandling af naturen, som finder sted i det Kantske og i det Fichteske system, og hvori fornuften selv bliver sat i en overensstemmelse med naturen, - ikke i en sådan overensstemmelse, hvori fornuften måtte give afkald på sig selv el. måtte blive en mat efterligning af den, men måtte blive en overensstemmelse ved at den gestalter sig selv til natur af indre kraft.

Hvad angår de almene refleksioner, som dette skrift indledes med, om filosofiens behov, forudsætning, grundsætninger osv., så har de den fejl at være almene refleksioner, og har deres foranledning $i$, at med sådanne former som forudsætning, grundsætninger osv., bliver indgangen i filosofien stadig mere overspundet og tildækket, og det bliver derfor til en vis grad nødvendigt at indlade sig på dem, indtil der engang udelukkende bliver tale om filosofien selv. Visse af de mere interessante af disse genstande, kommer ellers endnu til at få en større udførelse. 


\section{Mange slags former, som forekommer ved den nu- værende filosoféren}

\section{Historisk anskuelse af filosofiske systemer}

En tidsalder, der har lagt så mange filosofiske systemer bag sig som fortid, synes at måtte nå den indifferens, som livet når, efter at det har forsøgt sig med alle former. Driften mod totalitet ytrer sig endnu som drift til fuldstændigt kundskab, når den forbenede individualitet ikke længere selv vover sig ud i livet. Så søger den sig selv gennem mangfoldigheden af det, som den har, for at skaffe sig illusionen af det, den ikke selv er. Idet den forvandler videnskaben til en kundskab, har den givet afkald på den levende deltagelse, som videnskaben fordrer, og opretholdt den som en fjern og rent objektiv skikkelse, og opretholdt sig selv i sin uforstyrrede, egenvillige særegenhed, mod alle krav om at hæve sig til almenhed. For denne slags indifferens, hvis den kommer ud af sit sneglehus og helt hen til nysgerrigheden, findes der intet mere passende, end at give en nyudviklet filosofi et navn, og - ligesom Adam udtalte sit herskab over dyrene ved at give dem navne - udtale herskabet over en filosofi gennem fundet af et navn. På denne måde rykker den op i rang med kundskaben. Kundskab vedrører fremmede objekter. I den viden om filosofi, som aldrig var andet end kundskab, har det indres totalitet ikke bevæget sig og hævdet sin friheds ligegyldighed fuldstændigt.

Intet filosofisk system kan unddrage sig muligheden af en sådan modtagelse. Ethvert er i stand til at blive behandlet historisk. Og ligesom enhver levende skikkelse samtidigt tilhører fremtoningen, så har en filosofi som fremtoning overleveret sig til den magt, som kan forvandle det til en død mening og til fortid lige fra begyndelsen. For at afsløre sig, kræver den levende ånd, som bor i en filosofi, at blive født gennem en beslægtet ånd. Som et fremmed fænomen, strejfer den forbi den historiske opførsel, der, på grund af en el. anden interesse, trækker sig hen til kundskaben om meninger, og den åbenbarer ikke sit indre. Det kan være den ligegyldigt om den må tjene til at forstørre den øvrige kollektion af mumier og den almindelige ophobning af tilfældigheder, for den er selv undsluppet mellem hænderne på den nysgerrige samlen på kundskaber. Denne holder fast på sit - i sammenligning med sandheden - ligegyldige standpunkt, og beholder sin selvstændighed, hvad enten den så antager el. forkaster meninger eller ikke kan bestemme sig. Den kan ikke få et andet forhold til filosofiske systemer end at de er meninger, og sådanne accidenser som meninger kan ikke gøre den noget. Den har ikke erkendt, at der findes sandhed.

Filosofiens historie vinder dog, når driften efter at udvide videnskaben, 
kaster sig over at videreføre en nyttigere side, - idet den nemlig ifølge Reinhold skal tjene til at trænge dybere ind i filosofiens ånd, end det hidtil er sket - og over at videreføre forgængernes ejendommelige opfattelser vedrørende udforskningen af den menneskelige erkendelses realitet, gennem nye ejendommelige opfattelser. Kun gennem et sådant kendskab til de hidtil forøvede forsøg på at løse filosofiens opgave, kunne forsøget endelig lykkes, hvis ellers dette held er forundt menneskeheden. ${ }^{4}$

Man ser, at målet for en sådan undersøgelse lægger en forestilling om filosofi til grund, ifølge hvilken denne skulle være en slags håndværkskunst, der lader sig forbedre gennem stadigt nyopfundne håndgreb. Enhver ny opfindelse forudsætter kundskaben om de allerede anvendte håndgreb og deres formål. Men efter alle hidtidige forbedringer tilbagestår stadig hovedopgaven, som Reinhold til syvende og sidst synes at tænke således, at der nemlig skulle kunne findes et endnu mere almengyldigt, sidste håndgreb, igennem hvilket værket selv laver sig for enhver, der blot bryder sig om at gøre sig bekendt dermed. Hvis det handlede om en sådan opfindelse og videnskaben var en fremmed behændigheds døde værk, så ville den perfektibilitet, som er duelig til mekaniske kunster, faktisk passe sig for den, og til enhver tid skulle alle hidtidige filosofiske systemer ikke anses for andet end store hoveders forøvelser. Men når det absolutte såvel som dets fremtoning, fornuften, evigt er ét og det samme (som det nu engang er), så har enhver fornuft, der har rettet sig mod sig selv og erkendt sig selv, produceret en sand filosofi og løst sig den opgave, der, ligesom sin opløsning, til alle tider er den samme. Når det i filosofien handler om fornuften, der erkender sig selv, og kun har med sig selv at gøre, så ligger også hele dens værk såvel som dens virksomhed i den selv, og med hensyn til filosofiens indre væsen findes der hverken forgængere el. efterfølgere.

Lige så lidt som der kan være tale om bestandige forbedringer, kan der være tale om ejendommelige opfattelser i filosofien. Hvorledes skulle det fornuftige være ejendommeligt? Hvad der er ejendommeligt ved en filosofi kan, netop fordi det er ejendommeligt, kun tilhøre systemets form, ikke filosofiens væsen. Hvis noget ejendommeligt virkelig udgjorde en filosofis væsen, så ville det ikke være filosofi. Og hvis et system erklærer, at noget ejendommeligt er dets væsen, så kunne det, på trods af dette, være udsprunget af en ægte spekulation, som blot er forlist i forsøget på at meddele sig i en videnskabs form. Den som er fanget $i$ en ejendommelighed, kan i noget andet ikke se andet end ejendommeligheder. Hvis partikulære opfattelser bliver tilladt en plads i filosofiens væsen og hvis Reinhold anser det, som han i nyere tid har vendt sig til, for en ejendommelige filosofi, så er det ganske vist muligt, med Reinhold, at betragte overhovedet alle de hidtidige måder at fremstille og løse 
filosofiens opgave på, som intet andet end ejendommeligheder og forøvelser, gennem hvilke dog - fordi vi (selv når vi blot skuer kysterne af filosofiens lykkelige øer, som vi længes efter, tilhyllet af stumperne fra strandede skibe og ikke kan få øje på et bevaret fartøj i deres bugter) ikke burde lade den teleologiske opfattelse fare - det vellykkede forsøg forberedende ville være blevet foranlediget.

Ikke mindre må man ud fra ejendommeligheden af den form, som den Fichteske filosofi har meddelt sig i, også kunne forklare, at Fichte om Spinoza kunne sige, ${ }^{5}$ at Spinoza ikke kunne have troet på sin filosofi, ikke kunne have haft den fulde indre levende overbevisning, - og om de gamle kunne sige, at selv det er tvivlsomt, om de har tænkt sig filosofiens opgave med bevidsthed.

Når her det egne systems ejendommelighed i formen, dens hele steniske ${ }^{6}$ beskaffenhed, producerer en sådan ytring, så består derimod ejendommeligheden $\mathrm{i}$ den Reinholdske filosofi $\mathrm{i}$ en tendens til udgrunden og begrunden, der giver sig meget i lag med ejendommelige filosofiske opfattelser, og gør sig historisk umage med disse. Kærligheden og troen på sandheden er tiltaget til en så ren og afskyelig højde, så han - for at skridtet ind i templet er udgrundet og begrundet på rette vis - opfører en rummelig forgård, i hvilket de, for at spare skridtet, sørger for længe at analysere og metodisere og fortælle, indtil de har ladet sig overtale til - som trøst for deres uduelighed for filosofi - at andres dristige skridt ikke har været andet end forøvelser og åndsforvirringer.

Filosofiens væsen er ligefrem bundløs for ejendommeligheder, og for at nå hen til den er det, hvis legemet udtrykker summen af ejendommeligheder, nødvendigt at styrte sig à corps perdu. ${ }^{7}$ Thi fornuften, der finder bevidstheden hildet i ejendommeligheder, bliver kun til filosofisk spekulation, hvis den hæver sig op til sig selv og kun betroer sig til sig selv og til det absolutte, som samtidigt er dens genstand. Ved dette vover den ikke andet end bevidsthedens endeligheder og for at overvinde disse og konstruere det absolutte $i$ bevidstheden, hæver den sig op til spekulation og har i begrænsningernes og ejendommelighedernes grundløshed grebet sin egen begrundelse i sig selv. Og fordi spekulationen er den eneste og almene fornufts virksomhed på sig selv, så må den (i stedet for i de forskellige tidsaldres og hoveders filosofiske systemer blot at se forskellige måder og rent-ejendommelige opfattelser), når den har befriet sin egen anskuelse fra tilfældigheder og begrænsninger, gennem de særlige former igennem den selv - for ellers finder den en ren mangfoldighed af forstandige begreber og meninger, og en sådan mangfoldighed er ingen filosofi. En filosofis sande ejendommelighed er den interessante individualitet, $i$ hvilken fornuften har organiseret sig en skikkelse ud af en særlig tidsalders byggeværktøj. Den særlige spekulative fornuft finder i denne ånd af sin ånd, kød af sit kød, den ser sig i denne som én og densamme og som et andet 
levende væsen. Enhver filosofi er fuldendt i sig og har totaliteten i sig, ligesom et ægte kunstværk. Lige så lidt som Apelles og Sophokles værker, hvis Raffael og Shakespeare havde kendt dem, blot ville have fremtrådt som forøvelser for dem, men som en beslægtet åndskraft, lige så lidt kan fornuften i tidligere skikkelser af sig selv, bare se nyttige forøvelser til sig selv. Og hvis Vergil havde betragtet Homer som en sådan forøvelse til sig selv og sin forfinede tidsalder, så ville hans værk være blevet en repetition for den.

\section{Behov for filosofi ${ }^{8}$}

Hvis vi nærmere betragter den særlige form som bærer en filosofi, så ser vi den på den ene side udspringe af åndens levende originalitet, som i den har fremstillet og selvstændigt gestaltet den splittede harmoni igennem sig selv. Og på den anden side ser vi den ud af den særlige form, som splittelsen bærer og ud af hvilket systemet fremstår. Splittelse er kilden til behovene for filosofi og den er, som tidsalderens dannelse, skikkelsens ufrit givne side. I dannelsen har det, som er det absoluttes fremtoning, isoleret sig fra det absolutte og fikseret sig som noget selvstændigt. Samtidigt kan fremtoningen ikke fornægte sit udspring og må være opsat på at konstituere sine begrænsningers mangfoldighed som en helhed. Begrænsningskraften, forstanden, binder alt hvad der er værdifuldt og helligt for menneskene til sin bygning, som den opstiller mellem menneskene og det absolutte, og den fastgør det gennem alle naturens og talenternes magter og udstrækker det til uendeligheden. Deri kan man finde hele totaliteten af begrænsninger, blot ikke selve det absolutte. Fortabt i delene, driver det forstanden til dennes uendelige udvikling af mangfoldighed, som - idet den tilstræber at udvide sig til det absolutte, men blot endeløst producerer sig selv - spotter den selv. Fornuften når kun det absolutte, når den træder ud af dette mangfoldige del-væsen. Jo fastere og mere skinnende forstandsbygningen er, desto uroligere bliver livets bestræbelse, der som del er forudindtaget i den, på at trække sig ud af den i friheden. Idet den træder ud i det fjerne som fornuft, er begrænsningernes totalitet samtidigt tilintetgjort og den bliver i denne tilintetgørelse relateret til det absolutte og samtidigt hermed bliver den begrebet og sat som ren fremtoning. Splittelsen mellem det absolutte og totaliteten af begrænsninger er forsvundet.

Forstanden efterligner fornuften i den absolutte sætten og den giver sig selv skær af fornuft gennem denne form, skønt det satte i sig selv er det modsatte, dvs. det endelige. Den gør dette med så meget større illusion, når den forvandler og fixerer den fornuftige negeren i et produkt. Det uendelige er, for så vidt det bliver modsat det endelige, et sådant af forstanden sat 
fornuftigt. Som fornuftigt udtrykker det kun for sig selv en negeren af det endelige. Idet forstanden fixerer det, sætter den det absolut overfor det endelige. Og refleksionen, som havde løftet sig til fornuft i det den ophævede det endelige, har atter fornedret sig til forstand, idet den fixerede fornuftens gøren i en modsætning. Ydermere prætenderer den nu endog at være fornuftig i dette tilbagefald.

Sådanne modsatte, der skulle gælde for fornuftsprodukter og absolutte, har dannelsen opstillet $\mathrm{i}$ forskellige former til forskellige tider og forstanden har anstrængt sig med disse. Modsætningerne, som ellers var betydningsfulde i form af ånd og materie, sjæl og legeme, tro og forstand, frihed og nødvendighed osv., og i mere indskrænkede sfærer endnu var betydningsfulde i mangfoldige arter og som påberåbte sig alle de menneskelige interessers vægtlodder, er i dannelsens fremgang gået over i form af modsætningen mellem fornuft og sanselighed, intelligens og natur og - for det almene begreb - i modsætningen mellem absolut subjektivitet og absolut objektivitet.

At ophæve sådanne fastlåste modsætninger er fornuftens eneste interesse. Interessen har ikke den betydning, at den sætter sig imod enhver modsætning og indskrænkning overhovedet. For den nødvendige spaltning er én af livets faktorer, som evigt modsættende danner sig, og for totaliteten er det kun muligt at være mest levende, når det sker via genoprettelse ud fra den højeste adskillelse. Fornuften sætter sig snarere imod forstandens absolutte fixering af spaltningen og så meget des mere, når de absolut modsatte selv er udsprunget af fornuften.

Når foreningsmagten forsvinder ud af menneskers liv og modsætningerne har mistet deres levende forbindelse og vekselvirkning og bliver selvstændige, da opstår behovet for filosofi. Det er derfor forsåvidt en tilfældighed, men under den givne spaltning et nødvendigt forsøg, at ophæve modsætningen mellem den fastlåste subjektivitet og objektivitet, og at begribe den intellektuelle og reelle verdens blevet'hed som en tilblivelse, og at begribe deres væren blevet produkter som en producéren. Fornuften har i denne tilblivelses uendelige virksomhed og producéren forenet det, som var blevet adskildt, og har nedsat den absolutte spaltning til en relativ, som er betinget af den oprindelige identitet. Det er tilfældigt hvornår og hvor og i hvilken form en sådan selvreproduktion af fornuften optræder som filosofier. Denne tilfældighed må forstås ud fra, at det absolutte sætter sig som en objektiv totalitet. Tilfældigheden er en tilfældighed i tiden, såfremt det absoluttes objektivitet anskues som en fremadgåen i tiden. Men såfremt de fremtræder som sideordnede i rummet, er spaltningen klimatisk. Og i form af en fixeret refleksion - som en verden af tænkende og tænkte væsener, i modsætning til en verden af virkelighed - falder denne spaltning $i$ det vestlige norden. 
Jo længere dannelsen lykkes og jo mangfoldigere livsytringernes udvikling bliver, i hvilket spaltningen kan knytte sig sammen, desto større bliver spaltningens magt; desto fastere bliver dens klimatiske hellighed, desto mere fremmed bliver den for dannelsens helhed og desto betydningsløsere bliver livets bestræbelser på at genfødes til harmoni. Sådanne - i relation til helheden få forsøg, som har fundet sted imod den nyere dannelse, og de betydningsfulde, skønne skikkelsesdannelser fra fortiden el. fra det fremmede, har kun kunnet vække den opmærksomhed, hvis mulighed bliver tilbage, når den levende kunsts dybere, ærlige relation ikke kan vinde forståelse. Når livsforholdenes hele system fjernes fra den, er begrebet om dens altomfattende sammenhæng forsvundet og gået over i overtroens el. i den underholdende legs begreb. Den højeste æstetiske fuldkommenhed - sådan som den former sig i en bestemt religion, $i$ hvilken mennesket hæver sig over enhver splittelse og $\mathrm{i}$ nådens rige ser subjektets frihed og objektets nødvendighed forsvinde - har kun kunnet være energisk indtil et vist dannelsestrin og $i$ alment eller i pøbelbarbari. Den fremskridende kultur har adskildt sig fra den og stillet den ved siden af sig el. sig ved siden af den. Og fordi dens forstand er blevet sikker, trives begge i en vis ro side om side fordi de deler sig i helt adskildte områder, for hvilke det ingen betydning har hvad der foregår på det andet .

Men forstanden kan også umiddelbart angribes af fornuften på sit eget område, og forsøget på at tilintetgøre splittelsen og dermed dens absoluthed gennem refleksion, kunne have været forstået tidligere. Og på grund af dette havde den splittelse, der følte sig angrebet, så længe vendt sig mod fornuften med had og vrede, indtil forstandens rige havde svunget sig op til en sådan magt, hvori den kan holde sig sikker for fornuften.

Men på samme måde som man om dyden plejer at sige, at det største vidnesbyrd om dens realitet er det skin, som hykleriet låner fra den, så kan heller ikke forstanden værge sig mod fornuften, og den søger at beskytte sig mod følelsen af indre indholdsløshed og mod den skjulte frygt, som begrænsningen plages af, gennem et skin af fornuft, hvorved den dog overkalker sine særegenheder. Foragten for fornuften viser sig ikke stærkest $i$ at den frit forsmås og smædes, men $i$ at begrænsningen berømmer sit mesterskab over filosofien og sit venskab med den. Filosofien må afslå venskabet med sådanne falske forsøg, der uredeligt bryster sig af tilintetgørelsen af særegenheder, men som går ud fra begrænsninger og anvender filosofien som et middel til at redde og sikre disse begrænsninger.

I kampen mellem forstanden og fornuften får hin kun styrke hvis denne giver afkald på sig selv. Kampens heldige udfald afhænger derfor af denne selv og af ægtheden af behovet for genoprettelse af totaliteten, fra hvilken den fremgår. 
Behovet for filosofi kan udtrykkes som dens forudsætning, når filosofien, der begynder med sig selv, skal blive gjort til en slags forgård, og der bliver i vore tider talt meget om en absolut forudsætning. Det man kalder filosofiens forudsætning, er intet andet end det udtalte behov. Når behovet herigennem er sat for refleksionen, så må der findes to forudsætninger.

Den ene er det absolutte selv. Det er målet, som bliver søgt. Det er allerede for hånden - hvorledes skulle det ellers kunne blive søgt? Fornuften producerer det kun, når den befrier bevidstheden fra begrænsningerne. Denne ophævelse af begrænsningerne er betinget af den forudsatte ubegrænsethed.

Den anden forudsætning ville have været bevidsthedens udtræden af totaliteten, spaltningen i væren og ikke-væren, $\mathrm{i}$ begreb og væren, $\mathrm{i}$ endelighed og uendelighed. Fra spaltningens standpunkt er den absolutte syntese noget hinsides - det ubestemte og skikkelsesløse som er modsat dens egne bestemtheder. Det absolutte er natten, og lyset er yngre end denne, og deres forskel er en absolut differens, så snart lyset udtræder af natten, - intetheden er det første, ud fra hvilket al væren og alt det endeliges mangfoldighed er udgået. Men filosofiens opgave består i at forene disse modsætninger, at sætte væren $i$ ikke-væren - som vorden, spaltningen i det absolutte - som dettes fremtoning, det endelige i det uendelige - som liv.

Men det er upassende at udtrykke behovet for filosofi som en forudsætning for denne, thi herved får behovet refleksionsform. Denne refleksionsform viser sig som modsigende sætninger, som der nedenfor skal blive tale om. Man kan kræve af sætninger, at de retfærdiggør sig. Retfærdiggørelsen af disse sætninger, som forudsætninger, skal endnu ikke være filosofien selv, og så tager udgrundelsen og begrundelsen fat før og udenfor filosofien.

\section{Refleksion som instrument for filosoféren}

Den form, som behovet for filosofi ville få, hvis det skulle udtales som forudsætning, giver overgangen fra filosofiens behov til instrumentet for filosoféren, refleksionen som fornuft. Det er filosofiens opgave at det absolutte skal blive konstrueret for bevidstheden; men da refleksionens producéren såvel som dens produkter kun er begrænsninger, så er dette en modsigelse. Det absolutte skal reflekteres, sættes; men dermed er det ikke sat, men blevet ophævet, for idet det blev sat, blev det begrænset. Formidlingen af denne modsigelse er den filosofiske refleksion. Det skal især vises, om refleksionen er i stand til at fatte det absolutte, og om den i sin bestilling, som spekulation, bærer nødvendigheden og muligheden, om den syntetiserer med den absolutte anskuelse og for sig selv, subjektivt, kan være ligeså fuldstændig som dens produkt - det i bevidstheden 
konstruerede absolutte - på én og samme tid skal være bevidst og bevidstløst.

Den isolerede refleksion, som sætten af modsatte, ville være en ophævelse af det absolutte. Den er evnen til væren og begrænsning. Men som fornuft har refleksionen forbindelse til det absolutte, og den er kun fornuft gennem denne forbindelse. Refleksionen tilintetgør kun sig selv og al væren og alt begrænset, hvis den sætter det i forbindelse med det absolutte. Men samtidig har det begrænsede sin beståen netop gennem sin forbindelse med det absolutte.

Fornuften fremstiller sig som det negative absoluttes kraft, dermed som absolut negéren, og samtidigt som kraften i sætningen af den modsatte objektive og subjektive totalitet. En gang imellem hæver den forstanden op over denne selv og driver den til en helhed af sin art; den forfører den til at producere en objektiv totalitet. Enhver væren er, fordi den er sat, en modsat, betinget og betingende. Forstanden fuldstændiggør sine begrænsninger gennem sætning af modsatte begrænsninger som betingelser. Disse behøver den samme fuldstændiggørelse, og dens opgave udvider sig i det uendelige. Refleksionen synes heri kun at være forstandig, men ledelsen til nødvendighedens totalitet er fornuftens andel og hemmelige virksomhed. Idet den gør forstanden grænseløs, finder denne og dens objektive verden sin undergang $\mathrm{i}$ den uendelige rigdom. For enhver væren, som forstanden producerer, er noget bestemt, og det bestemte har noget ubestemt foran sig og bag sig, og værens mangfoldighed ligger mellem to nætter, holdningsløs. Den hviler sig på intet, for det ubestemte er intet for forstanden og ender i intet. Forstandens selvrådighed formår at lade modsætningen mellem det bestemte og det ubestemte, mellem endeligheden og den opgivede uendelighed bestå uforenet ved siden af hinanden og at fastholde væren over for den ikke-væren, der er lige så nødvendig for den. Dens væsen forsøger at lave undtagelsesløs bestemmelse, men da det bestemte umiddelbart er begrænset af et ubestemt, så opfylder dens sætten og bestemmen aldrig opgaven. I selve den sætten og bestemmen der sker, ligger der en ikke-sætten og et ubestemt, dvs. altid atter selve opgaven, at sætte og at bestemme.

Hvis forstanden fixerer disse modsatte, det endelige og det uendelige, så at begge samtidigt skal bestå som modsat hinanden, så ødelægger den sig selv. For modsætningen mellem endeligt og uendeligt har den betydning, at dersom én af dem sættes, så ophæves den anden. Idet fornuften erkender dette, har den ophævet selve forstanden; dennes sætten ser for den ud som ikke-sætten, og dens produkter som negationer. Denne tilintetgørelse eller fornuftens rene sætten uden modsætninger ville, hvis den bliver modsat den objektive uendelighed, være den subjektive uendelighed - det frihedens rige, som er modsat den objektive verden. Men da dette i denne form selv er modsat og betinget, så må fornuften, for absolut at ophæve modsætningen, også 
tilintetgøre dette i dets selvstændighed. Den tilintetgør begge idet den forener dem; for de er kun derved, at de ikke er forenet. I denne forening består begge samtidigt; for det modsatte og altså begrænsede er hermed forbundet med det absolutte. Men det består ikke for sig selv, men kun såfremt det er sat $\mathrm{i}$ det absolutte, dvs. som identitet. Hvis det begrænsede tilhører den ene af de modsatte, altså relative totaliteter, er det enten nødvendigt eller frit; såfremt det hører til deres syntese, ophører dets begrænsning: det er på én gang frit og nødvendigt, bevidst og bevidsløst. Denne bevidste identitet $\mathrm{i}$ bevidstheden om det endelige og det uendelige, foreningen af begge verdener, den sanselige og den intellektuelle, den nødvendige og den frie, er viden. Som evne til det endelige bliver refleksionen og dens modsatte uendelige syntetiseret $\mathrm{i}$ fornuften, hvis uendelighed omfatter det endelige.

Hvis refleksionen gør sig til genstand for den, er dens højeste lov, som bliver givet til den af fornuften og hvorigennem den bliver til fornuften, dens tilintetgørelse. Som alt andet har den kun beståen i det absolutte, men som refleksion er den modsat dette. For derfor at bestå, må den selv give sig selvødelæggelsens lov. Den immanente lov, gennem hvilken den af egen kraft konstituerer sig som absolut, ville være modsigelsesloven, nemlig at dens væren-lov skal være og blive. Derved fixerede den sine produkter som absolut modsat det absolutte, gjorde det til sine evige lov at forblive forstand og ikke blive fornuft og at holde fast ved sit værk, der som modsætning til det absolutte intet er (og som begrænset er modsat det absolutte).

Sådan som fornuften derved bliver noget forstandigt og dens uendelighed bliver noget subjektivt, når den er sat i en modsætning, så er dens form, som udtrykker reflekteren som tænkning, netop duelig til denne tvetydighed og dette misbrug. Hvis ikke tænkningen bliver sat som selve fornuftens absolutte virksomhed, for hvilken der slet ikke gives nogen modsætning, men hvis tænkningen derimod kun antages at være en renere refleksion, dvs. en sådan hvori der kun abstraheres fra modsætningen, så kan en sådan abstraherende forstandstænkning ikke engang komme ud til den logik, som fornuften skal begribe i sig selv, og endnu mindre til filosofi. Væsenet el. tænkningens indre karakter som tænkning, bliver af Reinhold sat som den uendelige gentagelighed af én og netop den slags som én og på selv samme sted, i én og netop den slags og gennem én og på selv samme sted, eller som identitet. Man kunne gennem denne tilsyneladende karakter af identitet blive forledt til i denne tænkning at se fornuften. Men igennem dens modsætning a) mod anvendelse af tænkning, b) mod en absolut stofhed, bliver det klart, at denne tænkning ikke er den absolutte identitet, identiteten af subjekt og objekt, som ophæver begge i deres modsætning og fatter dem i sig selv, men er en ren identitet, dvs. én, der er opstået gennem abstraktion og betinget gennem modsætning - enhedens 
abstrakte forstandsbegreb, enhed af fikserede modsætninger. Reinhold ser alle hidtidige filosofiers fejl under den, blandt vor tids filosoffer så udbredte og så dybt rodfæstede vane, at forestille sig tænkningen - overhovedet og i sin anvendelse - som noget blot subjektivt. ${ }^{10}$

Hvis det var rigtig alvor med denne tænkninges identitet og ikke-identitet, så kunne Reinhold egentlig slet ikke gøre nogen forskel mellem tænkning og anvendelse af tænkningen. Hvis tænkningen er sand identitet og ikke noget subjektivt, hvorfra skal der så kunne komme noget, der er forskelligt fra tænkningen, en anvendelse, for nu slet ikke at tale om stoffet, der bliver postuleret til brug for anvendelsen? Når den analytiske metode behandler en virksomhed, så må denne $\mathrm{i}$ analysen forekomme den at være en syntetisk tilsynekomst, og gennem denne analyséren opstår fra nu af enhedens led og en mangfoldighed, der er modsat denne. Det som analysen fremstiller som enhed kaldes subjektivt, og tænkningen bliver karakteriseret som en sådan enhed, der er modsat mangfoldigheden; som en abstrakt identitet. På denne måde er den noget rent begrænset og dens virksomhed er en lovmæssig og regelret anvendelse på en ellers forhåndenværende materie, der ikke kan trænge igennem til viden.

Kun hvis refleksionen har forbindelse til det absolutte, er den fornuft og dens gerning en viden. Men dens værk forgår dog gennem denne forbindelse, og kun forbindelsen består og er erkendelsens eneste realitet. Der findes derfor ingen anden sandhed ved den isolerede refleksion el. ved den rene tænkning, end dens tilintetgørelse. Men det absolutte bliver herigennem en objektiv totalitet, en helhed af viden, en organisation af erkendelser, fordi det i filosoféren bliver produceret til bevidstheden af refleksionen. I denne organisation er enhver del samtidigt helheden, for den består i forbindelsen til det absolutte. Som en del, der har andre uden for sig, er den begrænset og den er kun til gennem de andre. Isoleret som begrænsning er den mangelfuld, mening og betydning har den kun gennem sin sammenhæng med helheden. Der kan derfor ikke være tale om at enkelte begreber for sig selv, om at enkelte erkendelser er viden. Der kan findes en mængde enkeltstående empiriske erkendelser; som erfaringsviden fremviser de deres retfærdiggørelse i erfaringen, dvs. i identiteten af begrebet og væren, af subjekt og objekt. De er netop derfor ingen videnskabelig viden, fordi de kun har retfærdiggørelsen $i$ en begrænset, relativ identitet og ikke legitimerer sig som nødvendige dele af en organiseret erkendelseshelhed i bevidstheden. Og fordi den absolutte identitet - forbindelsen til det absolutte i dem - ikke er blevet erkendt gennem spekulationen. 


\section{Spekulationens forbold til den sunde menneskeforstand}

Som den såkaldte sunde menneskeforstand ved, er også det fornuftige ligeledes enkeltheder, der er trukket ind $i$ bevidstheden fra det absolutte, lyspunkter, der i sig selv hæver sig op over totalitetens nat, og med hvilke mennesket hjælper sig fornuftigt gennem livet. For det er de rigtige standpunkter, som det går ud fra og vender tilbage til.

Men $\mathrm{i}$ virkeligheden har også mennesket kun en sådan tiltro til deres sandhed, fordi det absolutte ledsager det $\mathrm{i}$ en følelse og fordi dette alene giver dem betydningen. Men så snart som man tager den almene menneskeforstands sandheder for sig og isolerer dem som blot forstandige, som erkendelser overhovedet, så fremtræder de som skæve og som halvsandheder. Den sunde menneskeforstand kan blive forvirret af refleksionen. Så snart den indlader sig på den, så gør det, som den nu udsiger som refleksionssætning, krav på at gælde for en viden i sig selv, for erkendelse. Og den har opgivet sin kraft, nemlig kun at understøtte sine udsagn gennem den dunkle totalitet, der er forhåndenværende som følelse, og kun stritte imod den urolige refleksion med denne. Den sunde menneskeforstand udtrykker sig nok for refleksionen, men dens udsagn indeholder ikke også for bevidstheden dens forbindelse til den absolutte totalitet, men denne forbliver uudtrykt i det indre. Af denne grund forstår spekulationen nok den sunde menneskeforstand, men den sunde menneskeforstand forstår ikke spekulationens gøren. Spekulationen anerkender kun erkendelsens væren i totaliteten som erkendelsens realitet. For den har alt bestemt kun realitet og sandhed i den erkendte forbindelse med det absolutte. Den erkender af denne grund også det absolutte i det, som ligger til grund for den sunde menneskeforstands udsagn. Men da erkendelsen kun har realitet for den, forsåvidt den er i det absolutte, bliver det erkendte og vidste, sådan som det er udtalt for refleksionen og derved har en bestemt form, samtidigt tilintetgjort. Den sunde menneskeforstands relative identiteter, der helt gør krav på absoluthed sådan som de fremtræder i deres begrænsede form, bliver tilfældigheder for den filosofiske refleksion. Den sunde menneskeforstand kan ikke fatte hvordan det, der for den er umiddelbart sikkert og vist, samtidigt kan være ingenting for filosofien. For den føler i sine umiddelbare sandheder kun deres forbindelse med det absolutte, men den adskiller ikke denne følelse fra deres fremtoning, gennem hvilke de er begrænsninger, men dog også skal have bestand og absolut væren som sådanne, men forsvinder foran spekulationen.

Ikke alene kan den sunde menneskeforstand ikke forstå spekulationen, men den må også hade den, når den erfarer den; og når den ikke er i sikkerhedens fulde indifferens, må den også afsky og forfølge den. For ligesom væsenets identitet og dets udsagns tilfældighed er absolut for den sunde menneskeforstand, og den ikke formår at adskille fremtoningens grænser fra 
det absolutte, så er også det, som den adskiller i sin bevidsthed, absolut modsat, og det, den erkender som begrænset, kan den ikke forene i bevidstheden med det ubegrænsede. De er nok identiske i den, men denne identitet er og bliver en indre, en følelse, noget uerkendt og uudtalt. Sådan som den erindrer om det begrænsede og som det bliver sat i bevidstheden, således er det ubegrænsede absolut modsat det begrænsede for denne. Dette forhold el. forbindelse af det begrænsede til det absolutte, i hvilken forbindelse kun modsætningen er $\mathrm{i}$ bevidstheden, mens der derimod er fuldstændig bevidstløshed om identiteten, hedder tro. Troen udtrykker ikke det syntetiske ved følelsen el. ved anskuelsen. Den er et forhold til det absolutte fra refleksionen, som i dette forhold ganske vist er fornuft og ganske vist tilintetgør sig selv som adskillende og adskilt, og tilintetgør sine produkter - en individuel bevidsthed - men som alligevel stadig har beholdt adskillelsens form. Troens umiddelbare vished, som så ofte er blevet omtalt som bevidsthedens sidste og højeste, er intet andet end identiteten selv, fornuften, der dog ikke erkender sig selv, men ledsages af bevidstheden om modsætningen. Men spekulationen ophøjer den identitet til bevidsthed, som den sunde menneskeforstand er bevidstløs om, eller den konstruerer det, der i den almindelige forstands bevidsthed er nødvendig modsætning til den bevidste identitet. Og denne forening af det, der $\mathrm{i}$ troen er adskilt, er den en vederstyggelighed. Netop fordi det hellige og det guddommelige kun består som objekt $\mathrm{i}$ dens bevidsthed, så opdager den i den ophævede modsætning, i den identitet, der er for bevidstheden, kun ødelæggelse af det guddommelige.

Især må den almindelige menneskeforstand ikke se andet end tilintetgørelse i de filosofiske systemer, som opfylder den bevidste identitets fordring i en sådan ophævelse af splittelsen, hvorigennem det modsatte for én gangs skyld - særligt når et sådant ellers er fixeret gennem tidens dannelse - ophøjes til det absolutte og det andet bliver tilintetgjort. Her har spekulationen ganske vist som filosofi ophævet modsætningen, men den har i systemets form opløftet noget til absolut, der ifølge sin sædvanligt kendte form er begrænset. Den eneste side, som herved kommer i betragtning, nemlig den spekulative, er slet ikke forhånden for den almindelige menneskeforstand. Fra den spekulative side er det begrænsede noget helt andet, end det forekommer den almindelige menneskeforstand at være. For når det bliver opløftet til det absolutte, er det ikke mere dette begrænsede. Materialisternes materie eller idealisternes jeg; - hin er ikke længere den døde materie, der har et liv som modsætning og dannelse - og dette er ikke mere den empiriske bevidsthed, der som begrænset må sætte noget uendeligt udenfor sig. Spørgsmålet hører til filosofien, om systemet faktisk her renset den endelige fremtoning, som det forhøjede til det uendelige, fra al endelighed - om spekulationen i sin største afstand fra 
den almindelige menneskeforstand og dennes fixerede modsætninger, ikke er underlagt sin tids skæbne, absolut at have sat en form af det absolutte, altså noget, der ifølge sit væsen, er modsætning. Hvis spekulationen virkelig har befriet det endelige, som den gjorde uendeligt, fra alle former for fremtoning, så er det først og fremmest navnet som den almindelige menneskeforstand her støder sig på, selvom den ellers ikke tager notits af den spekulative bestilling. Når spekulationen kun rent faktisk forøger det endelige til uendeligt og dermed tilintetgør det, - og materie, jeg, forsåvidt de skal omfatte totaliteten, ikke mere er jeg, ikke mere er materie -, så mangler godt nok den filosofiske refleksions sidste akt, nemlig bevidstheden om dens tilintetgørelse. Og når så også - uagtet denne faktisk skete tilintetgørelse - det absolutte ved systemet endnu har beholdt en bestemt form, så er i det mindste den ægte spekulative tendens ikke til at tage fejl af, omend den almindelige menneskeforstand intet forstår af den. Idet den ikke engang får øje på det filosofiske princip nemlig at ophæve splittelsen, men kun ser det systematiske princip, og for én gangs skyld finder modsætningen ophævet til det absolutte og det andet tilintetgjort, så havde den endnu en fordel på sin side med hensyn til splittelsen. I den, såvel som i systemet, findes der en absolut modsætning, men den havde dog modsætningens fuldstændighed og bliver dobbelt ærgerlig.

Der tilkommer et sådant filosofisk system, som der klæber den mangel ved, at det ophæver noget til absolut som fra en hvilkensomhelst side endnu er modsat, - foruden dets filosofiske side - endnu en fordel og fortjeneste, som den almindelige forstand ikke bare intet begriber af, men som den også må afsky: - Fordelen består i på én gang at have nedslået hele massen af endeligheder, som hænger på det modsatte princip, gennem ophøjelsen af noget endeligt til et uendeligt princip. - Fortjenesten med hensyn til dannelsen er, at have gjort spaltningen så meget hårdere og dermed at have forstærket behovet for forening $\mathrm{i}$ totaliteten så meget des mere.

Den sunde menneskeforstands hårdnakkethed - som i kraft af sin træghed holder det bevidstløse sikret $\mathrm{i}$ dets oprindelige tyngde og modsætning til bevidstheden, og holder materien sikret mod den differens, som kun bringer lyset ind i den for atter at konstruere den til system i en højere potens - kræver velsagtens under nordlige klimaer en længere tidsperiode, for blot at blive så meget overvundet for hånden, at den atomistiske materie selv hensættes i det mangfoldigere, så trægheden først og fremmest hensættes gennem en mangfoldigere kombineren og nedbrydning af den og gennem den hermed skabte større mængde faste atomer, hensættes i en bevægelse på sin bund, så at menneskeforstanden $i$ sin forstandige driven og viden til stadighed forvirrer sig yderligere, indtil den gør sig i stand til selv at udholde ophævelsen af denne forvirring og af selve modsætningen. 
Når kun den tilintetgørende side af spekulationen fremstår for den sunde menneskeforstand, så fremstår denne tilintetgørelse heller ikke for den i sit hele omfang. Hvis den kunne fatte dette omfang, ville den ikke anse den for sin modstander. For spekulationen kræver i sin højeste syntese af det bevidste og det bevidstløse også tilintetgørelsen af bevidstheden selv, og fornuften sænker dermed sin reflekteren af den absolutte identitet og af sin viden og af sig selv i sin egen afgrund, og i denne blotte refleksions og ræsonnerende forstands nat, som er livets middagstime, kan de begge mødes.

\section{Princippet for en filosofi i form af en absolut grundsatning}

Som totalitet af viden, der er produceret gennem refleksion, bliver filosofien et system, en organisk helhed af begreber, hvis højeste lov ikke er forstanden, men fornuften. Hin behøver at fremvise sine loves modsætninger, sin grænse, grund og betingelse rigtigt, men fornuften forener disse modsigende, den sætter begge samtidigt og ophæver begge. Der kan ske den fordring til systemet, forstået som en organisation af sætninger, at det absolutte, som ligger til grund for refleksionen, også skal være til for systemet på refleksionsvis som øverste absolutte grundsætning. Men en sådan fordring bærer allerede sin tomhed i sig. For det, der er sat gennem refleksion, en sætning, er for sig begrænset og betinget og behøver noget andet som sin begrundelse osv. i det uendelige. Når det absolutte bliver udtrykt $i$ en grundsætning, der er gyldig gennem og for tænkningen, og hvis form og materie er ens, så er enten den nøgne lighed sat og uligheden af form og materie udelukket og grundsætningen er betinget gennem denne ulighed. I dette tilfælde er grundsætningen ikke absolut, men mangelfuld; den udtrykker kun et forstandsbegreb, en abstraktion. Eller formen og materien er, som ulighed, samtidigt indeholdt i den, sætningen er analytisk og syntetisk samtidigt: så er grundsætningen en antinomi og dermed ikke en sætning, den står som sætning under forstandens lov om ikke at modsige sig selv, om ikke at ophæve sig selv, men den skal være sat. Men som antinomi ophæver den sig selv.

Denne vane, at noget, som kun blev sat for refleksionen, nødvendigvis må stå i spidsen af et system som øverste, absolutte grundsætning, eller at ethvert systems væsen kan udtrykkes i en sætning, der er absolut for tænkningen, gør sig arbejdet let med et system, som den anvender sin bedømmelse på. For det lader sig let påvise, at det tænkte, som sætningen udtrykker, er betinget af noget modsat, og derfor ikke er absolut. Ud fra sætningens modsætning bliver det påvist, at det må være blevet sat, at altså dét tænkte, som sætningen udtrykker, er tomt. Vanen anser sig så meget desto mere retfærdiggjort, når 
systemet selv udtrykker det absolutte, der er dets princip, i form at en sætning el. en definition, som dog i grunden er en antinomi og som derfor ophæver sig selv som noget sat for den rene refleksion. Sådan ophører f.eks. Spinozas substansbegreb - der på én og samme tid forklares som årsag og som bevirket, som begreb og som væren - med at være et begreb, da modsætningerne er forenet $\mathrm{i}$ en modsigelse.

Ingen begyndelse til en filosofi kan se dårligere ud end en begyndelse med en definition ligesom hos Spinoza - en begyndelse, der danner den sælsomste kontrast til dens begrunden, udgrunden, deduceren af vidensprincippet, den besværlige tilbageførelse af al filosofi til bevidsthedens højeste kendsgerning osv. Når fornuften har renset sig fra refleksionens subjektivitet, så kan også Spinozas indfald, som lader filosofien begynde med filosofien selv og som lader fornuften optræde lige så umiddelbart med en antinomi, blive behørigt værdsat.

Dersom filosofiens princip skal udtales i formale sætninger for refleksionen, så er der foreløbig ikke andet forhånden, der kan være genstand for denne opgave end viden, generelt syntesen af det subjektive og det objektive, eller den absolutte tænkning. Men refleksionen formår ikke at udtrykke den absolutte syntese i en sætning, når nemlig denne sætning skal gå for at være en egentlig sætning for forstanden. Den må dele det, der i den absolutte identitet er ét, og udtrykke syntesen og antitesen adskilt, i to sætninger, i den ene identiteten, $\mathrm{i}$ den anden splittelsen.

I A = A, identitetssætningen, bliver der reflekteret på forbundetheden, og denne forbinden, denne væren ens el. ligheden er indeholdt $\mathrm{i}$ denne rene identitet. Der bliver abstraheret fra al ulighed. A = A, den absolutte tænknings el. fornufts udtryk, har for den formale refleksion, der kun taler i forstandige sætninger, udelukkende betydning som forstandsidentitet, ren enhed, dvs. en sådan, hvori der er abstraheret fra modsætningen.

Men fornuften finder sig ikke udtrykt i den abstrakte enheds ensidighed. Den postulerer også sætningen af de, der blev abstraheret fra i den rene lighed, sætningen af det modsatte, uligheden. Det ene A er subjekt, det andet objekt, og udtrykket for deres differens er A ikke $=A$, eller A = B. Denne sætning modsiger rent ud den forrige. I den er - abstraheret fra den rene identitet og ikke-identitet - ikke-tænkningens ${ }^{11}$ rene form sat, ligesom den første sætter den rene tænknings form, der er en anden end den absolutte tænkning, fornuften. Kun fordi også den tænkte ikke-tænkning, A ikke = A bliver sat gennem tænkningen, kan den overhovedet være blevet sat. I A ikke $=\mathrm{A}$ eller i $\mathrm{A}=\mathrm{B}$ er identiteten, forbindelsen, ligeledes den første sætnings $=$, men kun subjektivt, dvs. kun forsåvidt ikke-tænkningen er sat gennem tænkningen. Men denne sathed af ikke-tænkningen for tænkningen er helt 
igennem tilfældig for ikke-tænkningen, den er den nøgne form af den anden sætning, som der må abstraheres fra for at få dens materie rent,

Denne anden sætning er lige så ubetinget som den første og forsåvidt betingelse for den første, som den første er betingelse for den anden sætning. Den første er betinget gennem den anden, forsåvidt den består gennem abstraktion fra den ulighed, som den anden sætning indeholder. Den anden er betinget, forsåvidt den behøver en forbindelse, for at være en sætning.

Ellers er den anden sætning blevet udsagt under grundsætningens subalterne form. Eller den er snarere blevet trukket ned i denne højst subalterne betydning ved at man har gjort den til kausalitetssætningen. At $A$ har en grund betyder: A tilkommer en væren, som ikke er A's væren, A er en væren-sat, der ikke er A's væren-sat. Altså A er ikke $=\mathrm{A}, \mathrm{A}=\mathrm{B}$. Hvis der bliver abstraheret fra at A er sat - som der må abstraheres fra, for at få den anden sætning rent så udtrykker den overhovedet A'ets ikke-væren-sathed. At sætte A som sat og ikke-sat samtidigt, er allerede syntesen af den første og den anden sætning.

Begge sætninger er modsigelsessætninger, blot i forkert betydning. Den første, identitetssætningen, udsiger, at modsigelsen $=0$. Den anden udsiger, forsåvidt den er forbundet til den første, at modsigelsen er lige så nødvendig som ikkemodsigelsen. Begge er, som sætninger, sat for sig med samme potens. Forsåvidt den anden bliver sådan udtrykt, at den første samtidigt er forbundet med den, så er den fornuftens højest mulige udtryk gennem forstanden. Forbindelse mellem dem er udtryk for antinomien, og som antinomi, som udtryk for den absolutte identitet, er det ligegyldigt om $\mathrm{A}$ sættes $=\mathrm{B}$ eller $\mathrm{A}$ sættes $=\mathrm{A}$, når nemlig $\mathrm{A}=\mathrm{B}$ og $\mathrm{A}=\mathrm{A}$ tages som begge sætningers forbindelse. $\mathrm{A}=\mathrm{A}$ indeholder på én gang differensen mellem A som subjekt og A som objekt og identiteten, lige som A $=\mathrm{B}$ indeholder identiteten af $\mathrm{A}$ og $\mathrm{B}$ med deres differens.

Hvis ikke forstanden genkender antinomien i grundsætningen, som er forbindelsen mellem begge, så er det ikke lykkedes den at blive fornuft, og formelt set er den anden sætning ikke ny for den. For den rene forstand udsiger $\mathrm{A}=\mathrm{B}$ ikke mere end den første sætning. Forstanden begriber nemlig derefter kun satheden af A som B som en gentagelse af A, dvs. den fastholder kun identiteten og abstraherer fra, at - idet A gentaget bliver sat som B eller i B - en anden, en ikke-A er blevet sat, og netop som $\mathrm{A}$, altså A som ikke-A.

Hvis man kun reflekterer over det formelle ved spekulationen og fastholder syntesen af viden $i$ analytisk form, så er antinomien - den selv-ophævende modsigelse - det højeste formelle udtryk for viden og for sandheden.

I antinomien har fornuften bragt refleksionens formale væsen under sig, når den bliver anerkendt som det formelle udtryk for sandheden. Men det formelle væsen har fået overtag, når tænkningen skal være blevet sat som det første sande i filosofien i den første sætnings eneste form, modsat den anden sætnings karak- 
ter af abstrakt enhed, og når der ud af analysen af anvendelsen af tænkningen skal være blevet oprettet et system af erkendelsens realitet. Derefter følger hele forløbet af denne rent analytiske bestilling på følgende måde.

Tænkningen er, som uendelig gentagelighed af A som A, en abstraktion, der udtrykker den første sætning som virksomhed. Nu mangler dog den anden sætning, ikke-tænkningen. Nødvendigvis må der nu gås over til denne som betingelsen for den første, og også denne, materien, må sættes. Hermed er de modsatte fuldstændige og overgangen er en særlig art af forbindelse mellem begge, som hedder anvendelsen af tænkningen og som er en højst ufuldkommen syntese. Men også denne svage syntese er selv snart i det uendelige, mod tænkningens forudsætning, som sætning af A som A. For i anvendelsen bliver A samtidig sat som ikke-A og tænkningen bliver i sin absolutte beståen ophævet som en uendelig gentagelse af $A$ som $A$.

Det, der er modsat tænkningen, er gennem sin forbindelse til tænkningen bestemt som et tænkt $=\mathrm{A}$. Men da en sådan tænkning, sætten $=\mathrm{A}$, er betinget af en abstraktion og dermed er en modsætning, så har også det tænkte, ud over at det er tænkt $=\mathrm{A}$, desuden andre bestemmelser $=\mathrm{B}$, som er helt uafhængige af deres nøgne bestemthed ud fra den rene tænkning, og disse er givet nøgent til tænkningen. Som princip for den analytiske filosoferen må der for tænkningen gives et absolut stof, som der nedenfor skal være mere tale om. Grundlaget for denne absolutte modsætning tillader ikke den formale bestilling - som den berømte opfindelse: at tilbageføre filosofien til logikken ${ }^{12}$ beror på - nogen anden immanent syntese end forstandsidentitetens, nemlig at gentage A i det uendelige. Men selv for at gentages behøver den et B, et C osv., i hvilke det gentagne A kan blive sat. Disse B, C, D osv. er - for A's gentageligheds skyld - en mangfoldighed, som er modsat sig selv. Ingen af dem har satte, særlige bestemmelser gennem A - dvs. det er et absolut mangfoldigt stof, hvis B, C, $\mathrm{D}$ osv. må føje sig til $\mathrm{A}$, som det nu kan. En sådan forvrøvlet sammenføjning træder i stedet for en oprindelig identitet. Grundfejlen kan præsenteres som, at der $\mathrm{i}$ formal henseende ikke er reflekteret på antinomien af $\mathrm{A}=\mathrm{A}$ og $\mathrm{A}=$ B. Bevidstheden lægger ikke et sådant analytisk væsen til grund, for at den rent formale fremtræden af det absolutte er modsigelsen, - en bevidsthed der kun kan opstå, når spekulationen tager udgangspunkt i fornuften og i $\mathrm{A}=\mathrm{A}$ som absolut identitet af subjekt og objekt.

\section{Transcendental anskuelse}

Hvis spekulationen betragtes fra den rene refleksions side, fremtræder den absolutte identitet i synteser af modsætninger, altså i antinomier. De relative 
identiteter, i hvilke det abslutte differentierer sig, er ganske vist begrænsede og for så vidt er de for forstanden og ikke antinomiske; men samtidig er de, da de er identiteter, ikke rene forstandsbegreber; og de må være identiteter, fordi der i en filosofi ikke kan være noget, der står uden forbindelse til det absolutte. Fra denne forbindelses side er selv ethvert begrænset en (relativ) identitet og for så vidt er det antinomisk for refleksionen, - og dette er den negative side af viden, det formale, der ødelægger sig selv, da det er regeret af fornuften. Uden for den negative side har viden en positiv side, nemlig anskuelsen. Ren viden (dvs. viden uden anskuelse) er tilintetgørelsen af modsætningerne i modsigelsen. Anskuelse uden denne syntese af modsætninger, er empirisk, given, bevidstløs. Den transcendentale viden forener begge, refleksion og anskuelse; den er begreb og væren samtidig. Idet anskuelsen bliver transcendental, indtræder identiteten af det subjektive og det objektive, som er adskilt i den empiriske anskuelse, i bevidstheden. Viden sætter, såfremt den bliver transcendental, ikke blot begrebet og dens betingelse - eller deres antinomi, det subjektive -, men samtidigt det objektive, væren. I filosofisk viden er det anskuede intelligensens og naturens virksomhed, det bevidste og det bevidstløse samtidigt. Det tilhører samtidig begge verdener, den ideelle og den reelle - den ideelle, idet det er sat i intelligensen og dermed $i$ friheden - den reelle, idet det har sit sted i den objektive totalitet, som en ring bliver deduceret i nødvendighedens kæde. Hvis man stiller sig på refleksionens eller frihedens standpunkt, så er det ideelle det første og væsenet og væren er kun den skematiserede intelligens. Stiller man sig på nødvendighedens el. værens standpunkt, så er tænkningen kun den absolutte værens skema. I den transcendentale viden er begge forenet, væren og intelligens. Ligeledes er transcendental viden og transcendental anskuelse ét og samme. De forskellige udtryk tyder blot på overvægt af den ideelle el. af den reelle faktor.

Det er af dybeste betydning, at det med så meget alvor er blevet hævdet, at man ikke kan filosofere uden transcendental anskuelse. Hvad betyder det, at filosofere uden anskuelse? At sprede sig endeløst $\mathrm{i}$ absolutte endeligheder. Disse endeligheder være nu subjektive el. objektive, begreber el. ting, eller der skal blive gået over fra den ene art til den anden, så går denne filosoferen uden anskuelse alligevel frem ad en endeløs række af endeligheder, og overgangen fra væren til begreb el. fra begreb til væren er ikke et retfærdiggjort spring. En sådan filosoferen kaldes formal, for hver for sig er ting og begreb kun en form af det absolutte. Den forudsætter absolut modsætning mellem væren og begreb og ødelæggelsen af den transcendentale anskuelse. $O g$ når den taler om det ubetingede, så laver den igen selv dette til noget formalt der skal være modsat væren, omtrent i form af en idé. Jo bedre metoden er, jo grellere bliver resultaterne. For spekulationen er endelighederne radier af det uendelige 
fokus, som udstråler dem og samtidigt er dannet af dem. I dem er fokus'et sat og i fokus'et er de sat. I den transcendentale anskuelse er alle modsætninger ophævet, og enhver forskel på konstruktionen af universet gennem og for intelligensen og på dens organisation - anskuet som noget objektivt, uafhængigt fremtrædene - er tilintetgjort. Bevidsthedens producéren af denne identitet er spekulationen, og idet idealitet og realitet er ens i den, er den anskuelse.

\section{Fornuftens postulater}

Som refleksionens værk krævede syntesen af de to modsætninger, som refleksionen satte, sin fuldstændiggørelse, - men som antinomi, der ophæver sig selv, sin beståen i anskuelsen. Da den spekulative viden må begribes som identitet af refleksion og af anskuelse, kan man i det tilfælde, hvor andelen af refleksionen (der, som fornuftig, er antinomisk) bliver sat alene, men står i nødvendig forbindelse til anskuelsen, sige om anskuelsen, at den vil blive postuleret af refleksionen. Der kan ikke være tale om at postulere ideer. For disse er fornuftens produkter eller snarere det fornuftige, sat som produkt gennem forstanden. Det fornuftige skal blive deduceret efter sit bestemte indhold, nemlig fra modsigelsen mellem bestemte modsætninger, hvis syntese er det fornuftige. Kun den anskuelse er det postulérbare, der kan udfylde og holde dette antinomiske. En sådan ellers postuleret idé er den uendelig progression, en blanding af empirisk og fornuftigt; hin er anskuelsen af tiden, denne er ophævelsen af enhver tid, uendeliggørelsen af den. I den empiriske progression er den imidlertid ikke rent uendeliggjort, for den skal i den bestå som endelige, som begrænsede momenter, - den er en empirisk uendelighed. Den sande antinomi, der ikke sætter det begrænsede og det ubegrænsede ved siden af hinanden, men samtidig sætter dem som identiske, må dermed samtidigt ophæve modsætningen. Idet antinomien postulerer den bestemte anskuelse af tiden, må denne - nutidens begrænsede moment og ubegrænsetheden af dens væren-sat udenfor sig selv - være begge samtidigt, altså være evigheden.

Lige så lidt kan anskuelsen blive krævet som en anskuelse af ideen eller - bedre - af modsætningen til den nødvendige antinomi. Den anskuelse, der er modsat ideen, er begrænset eksistens, netop fordi den udelukker ideen. Anskuelsen er nok fornuftens postulat, men ikke som begrænset, derimod som noget, der skal fuldstændiggøre énsidigheden af refleksionens værk, - ikke for at de skal forblive modsatte, men for at de skulle være ens. Overhovedet ser man, at denne postulérens hele måde alene har sin grund i, at der gås ud fra refleksionens énsidighed. Denne énsidighed er nødvendig for den, for at supplere dens mangelfuldhed, der består $\mathrm{i}$ at postulere den modsætning, der er 
udelukket fra den. Fornuftens væsen får imidlertid i denne opfattelse en skæv stilling, for den fremtræder her som en, der ikke er selvtilstrækkelig, men en trængende. Men hvis fornuften erkender sig selv som absolut, så begynder filosofien dér, hvor den manér, der udgår fra refleksionen, ophører: med identiteten af ideen og af væren. Den postulerer ikke det ene, for den sætter med absolutheden umiddelbart begge, og fornuftens absoluthed er ikke andet end identiteten af dem begge.

\section{Filosoférens forbold til et filosofisk system}

Behovet for filosofi kan tilfredsstilles ved at den bliver princippet for tilintetgørelsen af alle fixerede modsætninger og bliver gennemtrængt af det begrænsedes forbindelse til det absolutte. Denne tilfredsstillelse i princippet for den absolutte identitet træffes i filosoféren overhovedet.

Det kendte ville ifølge sit indhold være tilfældigt, og splittelserne, hvis tilintetgørelse det gik ud på, ville være givet og forsvundet og ikke selv være rekonstruérbare synteser. Indholdet af en sådan filosoferen ville overhovedet ikke have nogen sammenhæng og ville ikke udgøre en objektiv totalitet af viden. Alene på grund af sit indholds manglende sammenhæng, er denne filosoféren netop ikke nødvendigvis en ræsonnéren. Sidstnævnte spreder kun det satte $\mathrm{i}$ større mangfoldighed og når den, efter at være styrtet $\mathrm{i}$ denne strøm, svømmer holdningsløst, så skal hele den selv holdningsløse udstrækning af den forstandige mangfoldighed forblive bestående. For den sande, skønt usammenhængende filosoféren derimod, forsvinder det satte og dets modsatte, idet den ikke blot bringer det i sammenhæng med andre begrænsede, men i forbindelse med det absolutte og dermed ophæver det.

Men da denne forbindelse fra det begrænsede til det absolutte er mangfoldig, da det er de begrænsede, så må filosoféren gå ud på, at sætte denne mangfoldighed som sådan i forbindelse. Så må der opstå et behov for at producere en totalitet af viden, et videnskabssystem. Først herigennem befrier hine forbindelsers mangfoldighed sig fra tilfældigheden, idet de opnår at få deres plads sat i sammenhæng med den objektive videnstotalitet og deres objektive fuldstændighed bliver dermed bragt i stand. Den filosoféren, der ikke konstruerer sig til et system, er en bestandig flugt fra begrænsningerne - mere fornuftens kamp for frihed, end dens rene selverkendelse, der er blevet sikker på sit og klar over sig selv. Den frie fornuft og dens gerning er et, og dens virksomhed er en ren fremstilling af den selv.

I denne selvproduktion af fornuften gestalter det absolutte sig i en objektiv totalitet, der er en båret og fuldendt helhed i sig selv, der ingen grund har 
udenfor sig selv, men som er begrundet af sig selv i sin begyndelse, midte og ende. Sådan en helhed fremtræder som en organisation af sætninger og anskuelser. Hver af fornuftens synteser og deres korresponderende anskuelser, som begge er forenet i spekulationen, er - som identitet af det bevidste og det bevidstløse - for sig selv i det absolutte og er uendelig. Samtidigt er de endelige og begrænsede, såfremt de er sat i den objektive totalitet og har andre uden for sig. Den mest uspaltede identitet - objektivt materien, subjektivt følelsen (Selvbevidsthed) - er samtidigt noget uendeligt modsat, en helt igennem relativ identitet. Fornuften, evnen til (forsåvidt den objektive) totalitet, fuldstændiggør den gennem dens modsatte og producerer gennem deres syntese en ny identitet, der selv atter for fornuften er mangelfuld, men som ligeledes atter fuldfører sig selv. Systemets metode, der hverken kan kaldes syntetisk eller analytisk, giver sig i sin reneste form, når det fremtræder som fornuftens egen udvikling, som ikke til stadighed tilbagekalder sin fremtrædens emanation i sig selv - hermed tilintetgør den kun denne -, men konstruerer sig i den til en identitet, der er betinget af hin duplicitet, og atter modsætter sig denne relative identitet, således at systemet går frem til den fuldendte objektive totalitet og forener den med det modstående subjektive til en uendelig verdensanskuelse, hvis ekspansion dermed samtidigt har kontraheret sig til den rigeste og enkleste identitet.

Det er muligt, at den ægte spekulation ikke udtrykker sig fuldstændigt i sit system eller at systemets filosofi og systemet selv ikke falder sammen, at et system på det bestemteste udtrykker tendensen til at tilintetgøre alle modsætninger, men ikke for sig selv trænger igennem til den fuldstændigste identitet. Adskillelsen mellem disse hensyn er særligt vigtig i bedømmelsen af filosofiske systemer. Når et systems grundliggende behov ikke har gestaltet sig fuldkomment og kun har opløftet noget betinget til modsætningen mellem bestående og absolut, så bliver det som system dogmatisme. Men den sande spekulation kan finde sig selv i de forskelligste filosofier der gensidigt udskriger hinanden som dogmatisme og åndsvildfarelse. Filosofihistorien har alene værdi og interesse, når den fastholder dette synspunkt. Ellers giver den ikke historien om den evige og ene fornuft, der fremstiller sig i uendeligt mangfoldige former, men intet andet end en fortælling om den menneskelige ånds tilfældige begivenheder og betydningsløse meninger, som fornuften bliver bebyrdet med, da den dog kun ligger de til last, der ikke erkender det fornuftige i dem og af den grund har fordrejet dem.

Men en ægte spekulation, der ikke trænger igennem til sin fuldstændige selvkonstruktion i systemet, går nødvendigvis ud fra den absolutte identitet. Spaltningen af denne i subjektivt og objektivt er det absoluttes produkt. Grundprincippet er m.a.o. helt transcendentalt, og fra dets synspunkt er der ingen absolut modsætning mellem det subjektive og det objektive. Men 
dermed er det absoluttes fremtoning en modsætning; det absolutte er ikke i sin fremtoning; begge er selv modsatte. Fremtoningen er ikke identitet. Denne modsætning kan ikke bliver ophævet transcendentalt, dvs. ikke således, at der i sig selv ikke er nogen modsætning. Dermed bliver kun fremtoningen tilintetgjort, og dog skal den ligeledes være. Det ville blive hævdet, at det absolutte ville være gået ud af sig selv i sin fremtoning. Altså må det absolutte selv sætte sig i sin fremtoning, dvs. ikke tilintetgøre det, men konstruere den til identitet. Kausalforholdet mellem det absolutte og dets fremtræden, er en falsk identitet. For til grund for dette forhold ligger den absolutte modsætning. I den består begge de modsatte, men med forskellig rang. Foreningen er voldsom, den ene får den anden under sig; den ene hersker, den anden bliver undergiven. Enheden er fremtvunget $i$ en kun relativ identitet. Identiteten, der skal være en absolut, er ufuldstændig. Systemet er, med sin filosofi, blevet til dogmatisme - til en realisme, der sætter objektiviteten absolut, eller til en idealisme, der sætter subjektiviteten absolut - når begge (hvad der er mere tvetydigt ved hin end ved denne) er fremkommet af sand spekulation.

Den rene dogmatisme, som er en filosofiens dogmatisme, forbliver også i sin tendens immanent i modsætningen. Kausalforholdet er herskende som grundprincip i den, i dets fuldstændigere form som vekselvirkning, det intellektuelles indvirkning på det sanselige eller det sanseliges på det intellektuelle. I den konsekvente realisme eller idealisme, spiller det kun en underordnet rolle, selv når det synes at herske og selv når - $\mathrm{i}$ hin - subjektet bliver sat som objektets produkt og - i denne - objektet bliver sat som subjektets produkt. Kausalforholdet er ifølge sit væsen ophævet i det øjeblik en producéren er en absolut producéren, produktet er et absolut produkt, dvs. idet øjeblik produktet ikke har nogen anden bestand end i denne producéren, ikke er sat som selvstændigt bestående før og uafhængigt af denne producéren, som det er tilfældet $i$ et rent kausalforhold, der er det formelle princip for dogmatismen. I dette er det sat gennem et $\mathrm{A}$ og samtidigt også ikke sat af et A; A er altså kun subjekt, og A = A udtrykker kun forstandsidentiteten. Når filosofien også i sin transcendentale bestilling betjener sig af kausalforholdet, så er $\mathrm{B}$, der synes at være modsat subjektet, blot en mulighed $\mathrm{i}$ følge sin modsathed og det forbliver absolut en mulighed, dvs. det er kun akcidens. Og spekulationens sande forhold, substantialitetsforholdet, er under dække af kausalforholdet det transcendentale princip. Formelt lader dette sig også udtrykke således: Den sande dogmatisme anerkender begge grundsætninger $\mathrm{A}=\mathrm{A} \operatorname{og} \mathrm{A}=\mathrm{B}$, men de forbliver, $\mathrm{i}$ deres antinomi, usyntetiseret ved siden af hinanden. Den erkender ikke, at der heri ligger en antinomi og dermed heller ikke nødvendigheden af at ophæve de modsattes beståen. Den eneste mulige ufuldstændige syntese er for den overgangen fra den ene til den anden gennem 
et kausalitetsforhold. Uagtet at transcendentalfilosofien nu har denne skarpe forskel til dogmatismen, så er den i stand til at overgå til den, for så vidt den konstruerer sig til et system. Det kan den, når den nemlig - såfremt der ikke er andet end den absolutte identitet og når al differens og beståen af modsatte ophæver sig i den - ikke lader noget reelt kausalforhold gælde, men derimod indfører kausalforholdet, gør fremtrædelsen til undersåt og derfor kun sætter den transcendentale anskuelse subjektivt, ikke objektivt, og altså ikke sætter identiteten $\mathrm{i}$ fremtrædelsen - men alt dette kun såfremt fremtrædelsen består samtidigt og der dermed må eksistere et andet forhold mellem det absolutte og fremtrædelsen end den sidstnævntes tilintetgørelse. $\mathrm{A}=\mathrm{A}$ og $\mathrm{A}=\mathrm{B}$ forbliver begge ubetingede; kun A = A skal grlde. Men det vil sige at deres identitet ikke er fremstillet i deres sande syntese, der ikke er en ren skullen. Således er det absolutte i det Fichteske system Jeg $=$ Jeg. Fornuftens totalitet medfører den anden sætning, der sætter et ikke-Jeg. I denne antinomi af sætten, findes ikke kun begges fuldstændighed, men også deres syntese bliver postuleret. Men i denne forbliver modsætningen. Begge skal ikke - Jeg såvel som ikkeJeg - tilintetgøres, men den ene sætning skal bestå, den ene skal have højere rang end den anden. Systemets spekulation fordrer ophævelsen af modsatte, men systemet ophæver dem ikke selv. Den absolutte syntese, som det når, er ikke Jeg $=$ Jeg, men Jeg skal være lig Jeg. Det absolutte er konstrueret for det transcendentale synspunkt, men ikke for fremtoningens. De modsiger sig endnu. Da identiteten ikke samtidigt er blevet sat i fremtrædelsen eller da identiteten heller ikke er gået fuldkomment over i objektiviteten, så er transcendentaliteten selv noget modsat, det subjektive, og man kan tillige sige, at fremtoningen ikke er blevet tilintetgjort fuldstændigt.

Det skal i følgende fremstilling af det Fichteske system forsøges vist, at den rene bevidsthed, som i systemet er opstillet som absolut identitet af subjektet og objektet, er en subjektiv identitet af subjektet og objektet. Fremstillingen vil gå frem ved at vise Jeg'et, systemets princip, som subjektivt subjekt-objekt, såvel umiddelbart som i forbindelse med den art deduktion, naturen får, og i særdeleshed ved identitetens forhold i de særlige videnskaber om moral og om naturret og ved hele systemets forhold til det æstetiske.

Det fremgår allerede af det ovenstående, at der i denne fremstilling først og fremmest er tale om denne filosofi som system og ikke, for så vidt det er den grundigste og dybeste spekulation, en ægte filosoféren eller igennem den tid, i hvilken den fremtræder og i hvilken heller ikke den Kantiske filosofi ville kunne have begejstret fornuften til det forsvundne begreb om xgte spekulation, hvilket er så meget desto mere mærkværdigt. 


\section{Noter}

${ }^{1}$ [Skriftet kan findes i original i G.W.F. Hegel: Die Differenz des Fichte'schen und Schelling'schen Systems, (1801) in Wissenschaftliche Werksausgabe, Jubiläumsausgabe (Hrsg. Hermann Glockner) Stuttgart 1927ff. Bd. 1 (Aufsätze aus dem kritischen Journal der Philosophie und andere Schriften aus der jenenser Zeit); eller G.W.F. Hegel: : Jenaer Schriften 1801-1807 in Werke in zwanzig Bänden, Bd.2, Suhrkamp Verlag, Frankfurt am Main 1970; eller G.W.F. Hegel:: Jenaer Schriften 1801-1807 in Gesammelte Werke / Felix Meiner Sonderausgabe in 6 Bände, Bd. 1, 1999. Die Differenz des Fichte'schen und Schelling'schen Systems kan også fås som enkeltudgave (Studienausgabe) i Felix Meiner Philosophische Bibliothek. O.a.]

${ }^{2}$ [Kant fortæller overraskende og ikke ganske konsistent, at de 3 modalitetskategorier nok giver nødvendig erkendelse i subjektet, men - i mods. til de 9 andre kategorier - ikke udvider erkendelsen af objektet. Kritik der reinen Vernunft, B 266/A219.]

${ }^{3}$ Schleiermacher: Uber die Religion. Reden an die Gebildeten unter ihren Verächtern, Berlin 1799.

${ }^{4}$ Jf. Reinhold, Beiträge , I.Heft, s. 5f., 4

${ }^{5}$ Jf. Zweite Einleitung in die Wissenschaftslehre, SW, Bd.I, s. 513

${ }^{6}$ [gr. 'sthénos' = kraft, styrke; modsat 'asthénikos' = kraftløs, svag]

${ }^{7}$ [blindt, uoverlagt]

${ }^{8}$ [Hegels overskrift lyder:'Bedürfnis der Philosophie', som alternativt kunne oversættes: 'Filosofiens behov'. For Hegel kommer det nok ud på ét.]

9 ["Gesetz" betyder både "lov" og "sat" (førnutid af "setzen"). "Gesetzsein" kan derfor både oversættes "væren-lov" el. "væren-sat". O.a.]

10 samme, s. 96 [Reinhold, Beiträge, I.Heft.O.a.]

${ }^{11}$ Jf. Reinhold, Beiträge, I. Heft, s.111

${ }^{12}$ Reinhold, Beiträge, I.Heft, s. 9 